\title{
"We Will Not Watch Like Monkeys": Development Visions and Conflict Potentials in Northern Kenya
}

\author{
Kennedy Mkutu Agade
}

The remote, peripheral, particularly northern parts of Kenya, historically viewed as unproductive, have come into the spotlight as sites of great strategic importance, suitable for large-scale infrastructure development. The Kenyan government's Vision 2030 development blueprint sets out to address economic, social and political pillars of development and considers infrastructure an important enabler (Government of Kenya n.d.). Whereas Kenya's development visions have historically focused on investing in areas likely to produce the greatest economic (and political) returns (Zelezer 1991), Vision 2030 prioritizes the development of the northern arid and semi-arid lands (ASAL s). These areas are now recognized as having, among other things, considerable potential for oil, gas and mineral extraction, livestock production, tourism, and solar and wind power (Government of Kenya 2012a).

Perhaps as much as 6 o per cent of Kenya is made up of ASAL s occupied by pastoralists, whose livelihoods are wholly dependent on adaptation through mobility. Accordingly, land tenure is largely governed by custom and is communal in nature. Colonial and postcolonial governments have often undervalued these realities, and presumed that communal lands were unoccupied, so available for other purposes ranging from private ranching and irrigated agriculture to conservation and public projects. Although the Community Land Act of 2016 aimed to correct these injustices by providing for group registration and titling by indigenous inhabitants, for various reasons to be explored the protection offered may be ineffective (Wily 2018).

In this chapter, I consider the experiences of Turkana, Samburu and Isiolo counties in northern Kenya in which great change is anticipated, and interrogate the various visions of the future. The areas are all on the route of the planned Lamu Port, South Sudan, Ethiopia Transport Corridor (LAPSSET), one of the most ambitious infrastructure projects on the African continent, to include road, rail and an oil pipeline for transporting crude oil from fields in Turkana. New airports and resort cities are planned, together with dams to service the water needs of the latter (Government of Kenya n.d.). The state vision is supported by donors and development agencies; the North-Eastern

(C) KENNEDY MKUTU AGADE, 2022 | DOI:10.1163/9789004471641_017 
Development Initiative, a World Bank project, is also bringing roads, energy, water, sanitation, agriculture, and social protection (World Bank 2018).

Since colonial times, these counties have shared histories of economic, political and social marginalization. Another important similarity between them is that, since pastoralist communities compete for water and pasture in a drought-prone climate, resource-based conflicts are frequent and institutionalized. The conflict is facilitated and made more lethal by the availability of firearms in the region from neighbouring warring countries, and because staterun programmes have armed community members as National Police Reservists (Arero 2007; Mkutu 2008; Oba 2013). The lack of a formal state security presence has both allowed and stimulated the acquisition of arms for both offensive and defensive purposes. The new infrastructural developments complicate these pre-existing challenges, thus threatening land dispossession, exclusion, elite capture and conflict.

\section{Frontier Developments and Inequalities}

As states and/or investors advance into new spaces, both physical and metaphorical, they often do so with the apparent assumption that nothing already there is worthy of consideration, and that modern Eurocentric visions are inherently superior (Nyanjom 2014; Schetter 2012). Such assumptions dismiss the human value and agency within these spaces in terms of profitable economic systems and strategies; systems of governance and security; cultural and social institutions; and knowledge and skills capital. Notwithstanding the problems that come with lack of access to healthcare and education, and with vulnerability to natural disasters, there is much to be admired and embraced about pastoral social, political and economic systems, including a relatively classless society, the sustainable use of the environment and resilient livelihoods. However, neoliberalist and capitalist policies tend to advantage the 'haves' at the expense of the 'have nots' (Harvey 2003) while those less equipped in terms of wealth and educational capital are less able to anticipate and benefit from change (Elliot 2016).

Infrastructure is often seen as key to economic growth, though in fact where it is debt financed it may actually have the opposite effect (Banerjee et al. 2020). In a study of several infrastructure projects, Flyvbjerg et al. (2009: 179) found that the choice of projects was rarely down to suitability; costs were often strategically underestimated and benefits overestimated by project proponents, leading to 'survival of the least fit'. Moreover, investing in large-scale infrastructure inevitably leads to the neglect of investments in human capital, 
while rural or indigenous populations tend to bear the brunt of the negative impacts without feeling the positive ones (Suárez and Pérez 2018).

\section{Barrels of Prosperity: Inclusion and Exclusion in Turkana County}

In 2012, Kenya announced the discovery of commercially viable quantities of oil in the Turkana Basin in the northwest of the country. Within a few months, Turkana County had already seen massive change, and an influx of foreigners and non-Turkana people. Local expectations about the impending oil wealth were high, while in the political arena, various contesting groups were already talking about how to share the proceeds. The main players, Tullow Oil PLC and partners began extracting on a small scale in 2018 and planned to scale up operations after four years.

However, from the beginning, low-intensity conflict dogged Tullow's operations in Turkana. Before 2012, the production-sharing contract the company and government of Kenya signed was secretive and failed to involve Turkana's local government representatives at the time. Then, in the initial stages of the oil and gas exploration, participation processes were inadequate and local politicians became too dominant. Information was scanty and when local people began to see parts of their rangelands being fenced off, and sites allocated for surveying and later exploration, there was widespread fear and anger (Mkutu and Wandera 2016). In terms of environmental and social impacts, threats to water access, deforestation, toxic waste management and gas flaring were prominent concerns, and the new installations became a focus not only for small eateries and shops, but also for prostitution, alcohol sales and street children (Mkutu et al. 2019). By 2019, the company had detailed its plans to expand from 4 to 33 well pads (Tullow Oil 2019), and create a central processing facility while the national government gazetted around 15,500 acres for the activities of Tullow Oil PLC and 51,000 acres for the LAPSSET corridor (Obare 2019).

Expectations for jobs and tenders were initially high among locals, whom the company used for all unskilled labour positions. A particular thorn in the flesh, however, was that a local politician managed to profit from a leasepurchase scheme, agreed by Tullow and Toyota Kenya, to reward local entrepreneurs who employed local drivers to provide services to Tullow. Turkana drivers formed an association and complained bitterly. To make their voices heard, they created makeshift roadblocks outside the oil sites (Mkutu and Wandera 2016). Although community protests have so far been unarmed, they have sometimes severely disrupted company operations (Etyang 2018; Mkutu and Wandera 2016). 
Oil royalties, of which 5 per cent is supposed to go to the local community around the oil fields, have allegedly gone into the pockets of local politicians. Moreover, at the time of writing the company had just announced plans to sell its interests and, as of January 2020, has dramatically downscaled its operations, leaving the future uncertain with a possible takeover by a Chinese company on the horizon. Further, the drop in international oil prices and economic and political turmoil following the COVID-19 pandemic makes the prospect of future benefits trickling down to the locals even more uncertain.

'The Snake': Land Injustices and Vulture Capitalism Surrounding LAPSSET in Pastoral Counties

Since 2016, the National Land Commission has been compulsorily acquiring community land for the LAPSSET corridor, which is planned to pass through seven counties (Obare 2019). The corridor - or 'snake' as some informants have called it - is to be 2000 kilometres long and 500 metres wide (LCDA 2017). Furthermore, the government has stated its intention to allocate a special economic zone for 25 kilometres on either side of the corridor, to which private investors would be invited to develop industrial parks and mechanized agricultural farms (LCDA 2017).

Following a catalogue of historical injustices and conflicts, land was a key issue in Kenya's 2010 constitutional reforms, which culminated in several new legal provisions, including some to protect customary land tenure. However, in the absence of the full provisions of the Community Land Act of 2016 most land is as yet unregistered and held in trust by the county governments, with any compensation for land compulsorily acquired also held in trust until registration by the respective group. However, the powers of the county trust holders are vague and open to abuse, and local community members often lack the knowledge and political power they need to challenge them. Since official boundaries of community land are also vague, it is easily gazetted for other purposes without offering compensation (Wily 2018). A recent Land Value Index (Amendment) Act enacted in 2019 to streamline land acquisition for megaprojects is also insensitive to pastoralist realities; it decrees that unregistered community land will be valued at the market rate, which fails to recognize its value in sustaining pastoral livelihoods, and only recognizes people who have occupied the land for six years prior to its acquisition (Natural Justice 2019).

Currently, there is a great flurry of land speculation and illegal acquisition where LAPSSET is expected (Bonaya 2019; Elliot 2016). This has been intense in Isiolo (Enns 2019). Furthermore, there is an increase in individuals and 
groups marking out boundaries on communal land with fences, thorn bushes or painted boundary stones. ${ }^{1}$ In the Gotu area, Isiolo, a group of professionals from Isiolo and Marsabit pooled their resources in an attempt to acquire 33,00o acres of community land for a ranch. This was strategically located near the LAPSSET route and the Isiolo-Madogashe road currently being upgraded by the World Bank. The national government halted the acquisition after protests from the local community. ${ }^{2}$ The former governor claimed that national Ministry of Lands officials had colluded with land grabbers (Abdi 2015). A peace worker gave his opinion: "I think the government aims to displace the local people in Isiolo ... [the] majority of the local people are poor; they cannot keep up with these projects; a lot of immigrants from elsewhere will come to Isiolo and the majority of us will be displaced." ${ }^{3}$

Another important dimension of these concerns is a longstanding boundary dispute with Meru County, which LAPSSET plans and expectations have exacerbated. In 2018, there was an initiative by the Meru governor to provide services in the disputed areas and to issue title deeds. Many saw this as putting a Meru County stamp on the area and winning the hearts, minds (and votes) of those people. To add to all this, the top LAPSSET Corridor Development Authority officials have been people of Meru ethnicity. This layer of ethnopolitical competition further complicates the situation, and suggests that benefits will be politically distributed, leading to increased risk of conflict and less attention to development.

Participation is an important aspect of the injustices described. Despite a constitutional emphasis on it, people's visions about LAPSSET are limited because the participatory processes are not reaching them. LAPSSET Corridor Development Authority stated that it had meetings to which key community representatives and administrators were invited, but that it relied on the local administration to disseminate the information to most of the people, and acknowledged that this does not reliably happen. Thus, people fear the worst (often justifiably so) and are unable to prepare themselves either to benefit or to mitigate harm. A Ministry of Lands officer verified this dynamic of exclusion from participation when he said that he could tell the researchers where LAPSSET would pass, but that the members of the community had not been informed because 'they have interests.'

1 Observation, Isiolo, 2018-20.

2 Observation and interviews with local leaders and community members, Isiolo, August 2019.

3 Interview, Isiolo member of subcounty Peace and Cohesion Committee and Livestock Marketing Division, Isiolo, 22 March 2019.

4 Phone interview, Ministry of Lands officer, Nairobi, 11 March 2020. 
Lack of participation acts as a trigger for violence when community security actors (the warriors of pastoral groups) chase away visiting consultants connected with LAPSSET, as happened in Samburu County. ${ }^{5}$ A community member in Wamba, Samburu said, "All we know is [the word] LAPSSET, we do not know about it. First, we must know what it is all about. If they come with security and build here we will not watch like monkeys." ${ }^{\prime 6}$

Power Lines and Local Political Power in Samburu County

Samburu is one of a few counties in which pastoralist group ranches were established from the 196os onwards to safeguard land tenure for pastoralists, and to help the latter engage with the market economy. However, group ranches have faced several challenges, including the potential over-empowerment of local elites and of their ability to accumulate benefits. Many group ranches have become part of wildlife conservancies. The Kenya Electricity Transmission Company (KETRACO) is the government-owned company that implemented the Ethiopia-Kenya Transmission Line, which the two governments conceived in 2006 as part of the proposed Ethiopia-Kenya Power Systems Interconnection Project. The power line passed over several conservancies in Samburu and raised some inter-group disputes. Some local people unsuccessfully attempted to benefit privately from the compensation being offered by building manyattas (simple Samburu dwellings) along the proposed route. ${ }^{7}$ Then, when compensation was awarded collectively, this brought disputes about how to share the economic benefits.

In Namunyak conservancy there were two factions - those who wanted 'the ATM', namely cash transfers, and those who wanted community development projects. ${ }^{8}$ Those wanting cash feared that conservancy board members would monopolize the money and they would never see the benefits.

Recently, we got almost fifty million (Kenya shillings) from KETRACO as compensation ... what we saw is the eight million that was given to members. The remaining we were told will be kept for us; they will build for us

5 Interview, NGO staff member, Wamba, Samburu, 19 December 2019.

6 Interview, National Police Reservist, Wamba, Samburu, 18 February 2020.

7 Interview, West Gate conservancy staff, Samburu, 13 February 2020; Interview, Catholic priest in Wamba, Samburu, 16 February 2020.

8 Interview West Gate conservancy official talking about Namunyak, Samburu, 13 February 2020 . 
a project, so it goes on and on. ... All those golden opportunities like the snake (LAPSSET), they will pay to the group-ranch management. ${ }^{9}$

An almost identical dispute was taking place over the 21 million Kenya Shillings that KETRACO awarded to West Gate conservancy. ${ }^{10}$

A possible implication of LAPSSET passing through Samburu is the disintegration of some group ranches because of the commodification of the land. ${ }^{11}$ Large-scale subdivision and some private sales of group-ranch land have already been witnessed in Amboseli and Narok, creating many challenges to livelihoods and environmental impacts (Mkutu 2020). Furthermore, because empowered people such as local political leaders are likely to be allocated the more valuable parcels and others excluded altogether, this could raise tensions and create conflict. For many, pastoralism could be abandoned for more lucrative but perhaps less sustainable alternatives. Finally, one way to have compensated communities adequately for their losses would have been to provide electricity, either on or off grid. However, despite demands by the communities, the power lines simply pass through the county, leaving them in the dark. ${ }^{12}$

Conservancies are a popular and growing model of land use in Kenya, particularly in the remote pastoralist counties, and they now number about 160 and cover at least 11 per cent of Kenya's total land area (KWCA 2021). In the north of the country, most conservancies are part of an umbrella organization known as the Northern Rangelands Trust, which receives high levels of donor development funding to support their creation and ongoing management.

Controversially, despite the various benefits they bring to the communities, conservancies tend to formalize land claims, militarize communities and sometimes exacerbate conflict (Campbell et al. 2009; Government of Kenya $2012 b)$. Pastoralists and even administrators have at times proposed or established conservancies as a means of protecting land claims and controlling pastoralist migrations from elsewhere. That conservancies are allowed to use

9 Interview, retired civil servant and community development officer, Wamba, Samburu, 19 February 2020.

10 Interviews, West Gate conservancy, February 2020.

11 The Community Land Act of 2016 actually repeals former legislation recognizing groupranch titles, and group ranches have been asked to re-register. However, the governance structures and the risk of subdivision remain the same. 
armed national police reservists to carry out community and wildlife security (Mkutu 2020) provides a further incentive. These rangers, who are members of the local community, have occasionally been accused of involvement in lethal inter-communal conflicts (Greiner 2012; Okumu 2014). Moreover, the Northern Rangelands Trust facilitates training and equipment for the ranger teams and is involved in deployment decisions. This, however, raises potent ethical questions (Mkutu 2020), especially since the non-conservancy reservists, previously armed to supplement police efforts in remote areas, were disarmed in 2019. Some communities accuse conservation elites of using conservancies and their highly trained ranger teams to grab their land and access its resources (Mkutu 2020; Ogada 2020).

The issue of conservancies relates to the question of different visions about development in several ways. First, LAPSSET and the associated developments are going to interfere with wildlife corridors and there is already evidence of this, with dead giraffes and other grazers on the recently completed IsioloMoyale road, ${ }^{13}$ and stranded buffalo herds unable to cross between Shaba and Buffalo national reserves on either side of this road (Mkutu 2020). This increases human-wildlife conflict, which usually hits poorest communities hardest (Garland 2008), and these are the same communities already likely to be squeezed by LAPSSET. Second, in an attempt to mitigate this problem, the government has proposed creating protected wildlife corridors and existing conservancies are likely to feature strongly in this plan, together with the creation of new ones. This too will constrain pastoralist movements and multiply the other problems of conservancies. Third, the increased militarization of society is ominous where LAPSSET has increased the stakes for control over land, and where grievances among pastoral communities are highly likely to occur over injustices such as displacement (both by the corridor itself and associated land grabs in the special economic zone), and exclusion from jobs and other economic opportunities.

\section{$7 \quad$ From Conflicting Visions to Conflict}

These cases in the early stages of development in Turkana, Isiolo and Samburu illustrate the conflicting visions of the different actors. While promising to 'open up the north' and 'reverse years of marginalization', 
the state's emphasis on land-based infrastructural development is more likely to increase inequalities. With their enhanced vision of the future, empowered people are able to get ahead and land speculation is soaring in the LAPSSET areas. With devolution in Kenya, over the last seven years an increasing number of elites and brokers have been establishing bases in the counties, where they see opportunities to advance economically and politically, to accumulate and dispossess, by using their monopoly on knowledge and their ability to access links and networks with investors and the diaspora.

By contrast, many pastoralists lack education, access to information, and meaningful participation, and have few helpful connections, while local pastoralist elites may even corner the benefits given collectively. A lack of planning for inclusion in employment opportunities through skills training in advance of these developments makes it likely that skilled and semi-skilled labour will need to be imported, as in the case of Turkana, thus fuelling local grievances.

The anticipated development of LAPSSET has a potential to overcome the structural violence of exclusion. However, local people's distrust of the project may lead to a greater likelihood of social conflict around infrastructure development (Suárez and Pérez 2018). Conflict may take the form of state-community and community-investor conflict, as in Turkana; intra-communal tensions and conflict, as in Samburu; and intercommunal or ethno-political conflict, as in Isiolo. All these counties have large numbers of firearms in civilian hands and a high risk of violent conflict as the development visions proceed. Moreover, the terrorist organization Al Shabaab, which has already carried out several devastating attacks in Kenya, has threatened to attack Kenya's development projects (Watkins 2015). Since Al Shabaab relies upon locally based networks, these early findings suggest that inclusion is critical to development and may be the most potent way of avoiding conflict.

\section{Acknowledgements}

I wish to acknowledge the support of the Collaborative Research Centre (CRCTRR 228) 'Future Rural Africa: Future-Making and Social-Ecological Transformation' for the opportunity to carry out this work. I am also extremely grateful to the interviewees and participants of the three counties for their time and assistance. Thanks to Tessa Mkutu for her editing and the two reviewers for their useful comments. 


\section{References}

Abdi, A. 2015. “Speculators grab land on LAPSSET strip." Daily Nation, 2 March. https:// www.standardmedia.co.ke/article/2000153436/speculators-grab-land-on-lapssetstrip [1 May 2020].

Arero, H. W. 2007. "Coming to Kenya: Imagining and perceiving a nation among the Borana of Kenya." Journal of Eastern African Studies, 1, 2: 292-304. DoI: $10.1080 / 17531050701452598$.

Banerjee, A., E. Duflo and N. Qian. 2020. "On the road: Access to transportation infrastructure and economic growth in China." Journal of Development Economics, 145. DOI: 10.1016/j.jdeveco.2020.102442.

Bonaya, M. 2019. "Mind pastoral land, boundaries in Lapsset." Daily Nation, 7 November. https://nation.africa/kenya/blogs-opinion/opinion/mind-pastoral-land-boundaries-in-lapsset-220952 [6 March 2020].

Campbell, I., S. Dalrymple, R. Craig and A. Crawford. 20o9. Climate change and conflict: Lessons from community conservancies in northern Kenya. Nairobi/Winnipeg/ London: CDC/IISD/Saferworld.

Elliot, H. 2016. "Planning, property and plots at the gateway to Kenya's 'new frontier." Journal of Eastern African Studies, 10, 3: 511-29.

Enns, C. 2019. "Infrastructure projects and rural politics in northern Kenya: The use of divergent expertise to negotiate the terms of land deals for transport infrastructure." Journal of Peasant Studies, 46, 2: 358-376. Dor: 10.1080/03066150.2017.1377185.

Etyang, H. 2018. "Tullow Oil employees held hostage at Turkana Camp" The Star, 14 January. https://www.the-star.co.ke/news/2018/o1/15/tullow-oil-employees-heldhostage-at-turkana-camp_c16986o3 [10 May 2018].

Flyvbjerg, B., M. Garbuio and D. Lovallo. 20o9. "Delusion and deception in large infrastructure projects." California Management Review, 51, 2: 170-193.

Garland, E. 2008. "The elephant in the room: Confronting the colonial character of wildlife conservation in Africa." African Studies Review, 51, 3: 51-74.

Government of Kenya. 2012a. "National policy for the sustainable development of northern Kenya and other arid lands." Sessional paper no. 8. Nairobi: Government Printers.

Government of Kenya. 2012b. "Conservancies, conflicts and how they affect service delivery in Isiolo County: Sectoral briefing notes by MoSDNK\&oAL.” 25 April. Nairobi: Government Printers.

Government of Kenya. n.d. "About Vision 203o". https://vision203o.go.ke/aboutvision-2030/ [11 March 2020].

Greiner, C. 2012. "Unexpected consequences: Wildlife conservation and territorial conflict in northern Kenya." Human Ecology, 40: 415-425.

Harvey, D. 2003. The new imperialism. Oxford: Oxford University Press. 
KWCA (Kenya Wildlife Conservancies Association). 2021. "Facts and figures." https:// kwcakenya.com/conservancies/status-of-wildlife-conservancies-in-kenya/ [7 May 2021].

LCDA (LAPSSET Corridor Development Authority). 2017. Strategic environmental assessment. Nairobi: The Presidency and LCDA.

Mkutu, K. 2008. Guns and governance in the Rift Valley. Pastoralist conflict and small arms. Oxford: James Currey.

Mkutu, K. 2020. Security dynamics in conservation areas in Isiolo County. Working paper, Bonn: Bonn International Centre for Conversion.

Mkutu, K. and G. Wandera. 2016. Conflict, security and the extractive industries in Turkana, Kenya: Emerging issues 2012-2015. Nairobi: UsIU-Africa/Kenya School of Government.

Mkutu, K., T. Mkutu, M. Marani and A. L. Ekitela. 2019. "New oil developments in a remote area: Environmental justice and participation in Turkana, Kenya." Journal of Environment and Development, 28, 3: 223-252. DOI: 10.1177/1070496519857776.

Natural Justice. 2019. "Land Value Amendment Act 2019." Factsheet. https://naturaljustice.org/wp-content/uploads/2019/11/LVA-fact-sheet-1.pdf.

Nyanjom, O. 2014. Re-marginalizing Kenyan pastoralists of Kenya's ASALs: The hidden curse of national growth and development. African Study Monographs, Supp. $5^{\circ}$ : $43-72$.

Oba, G. 2013. Nomads in the shadows of empires: Contests, conflicts and legacies on the southern Ethiopian-northern Kenyan frontier. Leiden: Brill.

Obare, O. 2019. "Court stops compulsory acquisition of land for oil exploration in Turkana." The Standard, 12 March. https:/www.standardmedia.co.ke/business/ article/2001316308/government-blocked-from-acquiring-land-in-turkana [6 March 2020].

Ogada, M. 2020. "Why black lives don't matter in Kenya's colonial 'conservancies." The Elephant, 12 June. https:/www.theelephant.info/features/2020/06/12/why-blacklives-dont-matter-in-kenyas-colonial-conservancies/ [22 June 2020].

Okumu, W. 2014. "Conflict over Ltungai conservancy: A case of fatal competition over grazing land and water among the Samburu and the Pokot in northern Kenya." In A delicate balance: Land use, minority rights and social stability in the Horn of Africa, edited by M. G. Behre, 224-245. Addis Ababa: Institute for Peace and Security Studies.

Schetter, C. 2012. "Ungoverned territories." In Spatial dimension of risk, edited by D. Müller-Mahn, 97-108. London: Earthscan.

Suárez, E. R. and G. Pérez. 2018. "Development and conflicts linked to infrastructure construction." FAL Bulletin, 361, 1: 1-7. https://www.cepal.org/en/publications/43721 -development-and-conflicts-linked-infrastructure-construction.

Tullow Oil. 2019. "Foundation stage development ESIA stakeholder engagement plan.” https://www.tullowoil.com/our-operations/africa/kenya/environmental-social/. 
Watkins, E. 2015. "LAPSSET terrorism in the pipeline." Counter-Terrorist Trends and Analysis, 7, 8: 4-9.

Wily, L. A. 2018. "The Community Land Act in Kenya: Opportunities and challenges." Land, 7, 1: 12. DoI:10.339o/land7010012.

World Bank. 2018. "Boosting prosperity, improving equity in North and North Eastern Kenya." 8 May. https://www.worldbank.org/en/news/feature/2018/o5/o8/boostingprosperity-improving-equity-in-north-and-north-eastern-kenya [7 May 2020].

Zelezer, T. 1991. "Economic policy and performance in Kenya since independence." TransAfrican Journal of History, 20: 35-76. 